\title{
A FOGYASZTÓI ADÁSVÉTEL EGYES KÉRDÉSEINEK SZABÁlYOZÁSA ÉS JOGGYAKORLATA MAGYARORSZÁGON ${ }^{\mathrm{I}}$
}

FÉzer TAMÁs - Hajnal ZsolT

Debreceni Jogi Mühely, 2020. ÉVI (XVII. ÉVfolyam) I-2. DOI I $0.24169 / \mathrm{DJM} / 2020 / \mathrm{I}-2 / 2$

\section{A hibás teljesítés hazai szabályozásának kialakulása az irányelv hatálybalépését követően}

A hazai jogalkotó a minimum harmonizáción alapuló 1999/44/EK irányelvvel ${ }^{2}$ összhangban álló szabályokat fogadott el a 2002. évi XXXVI. törvény által, amely ekként jelentős módosításokhoz vezetett a Polgári Törvénykönyvről szóló 1959. évi IV. törvény (a továbbiakban: régi Ptk.) normaszövegében. A régi Ptk. 277. $\$$ teljesítésre vonatkozó szabályai az irányelv 2. cikk (1)-(4) bekezdéseivel, a régi Ptk. 248. $\$$ jótállásra vonatkozó rendelkezései az irányelv 6 . cikkében foglalt szabályokkal összhangban kerültek módosításra. A régi Ptk. 305311. \$-ának rendelkezései is módosultak és beiktatásra került az új 311/A. $\$$, a kellékszavatosság irányelvkonform szabályozását megteremtve. A módosítás az értelmező rendelkezések közé beillesztette a fogyasztó és a fogyasztói szerződés fogalmakat, a fogyasztói szerződésekre vonatkozóan pedig a hibás teljesítés szabályozása körében az általánostól eltérő, a gyengébb fél védelmét biztosító szabályokat iktatott be a régi Ptk. normaszövegébe. ${ }^{3}$

2014. március 15-én lépett hatályba a jelenleg is alkalmazandó Ptk., amely számos változást hozott a hibás teljesítésre vonatkozó normaanyagban. Megjegyzendő ugyanakkor, hogy a Kúria 1/2014. számú PJE határozatának 1. pontja alapján a Ptk. alkalmazása körében továbbra is megfelelően irányadónak tekinti a hibás teljesítéssel kapcsolatos egyes jogalkalmazási kérdésekről szóló 1/2012. (VI. 21.) PK vélemény 1-11. és 15 . pontjait.

1 A tanulmány megírása és megjelentetése az Igazságügyi Minisztérium jogászképzés színvonalának emelését célzó programjai keretében valósult meg.

2 Az Európai Parlament és a Tanács 1999/44/EK irányelve (1999. május 25.) a fogyasztási cikkek adásvételének és a kapcsolódó jótállásnak egyes vonatkozásairól, HL L 171., 1999.7.7., 12-16.

3 Varga N.: Gondolatok a fogyasztói szerződési jog kialakulásáról és fejlődéséről. Debreceni Jogi Mühely, Vol. 10, 2013/3. 138-157. https://mad-hatter.it.unideb.hu/portal/displayDocument/id/2482204ol. (letöltés dátuma: 2020.02.10.) 


\section{A szabályozás természete, a fogyasztó és vállalkozás között kötött szerződés meghatározása}

A Ptk. 8:1. \$ (1) bekezdésének 3. pontja alapján a fogyasztó a szakmája, önálló foglalkozása vagy üzleti tevékenysége körén kívül eljáró természetes személy, megfelelve ezáltal az 1999/44/EK irányelv 1. cikk (2) bekezdésének a) pontja szerinti meghatározásnak. A fogyasztóvédelem alanyának jogi dilemmájával több szerző is foglalkozott már kimerítően, ${ }^{4}$ a jogi dilemmák nagy része meghaladottnak mondható a Ptk. új, a jogvédelmet természetes személyekre leszűkítő megoldásának hatályba lépésével. Fuglinszky Ádám részletesen mutatja be a Ptk. alkalmazásával összefüggésben felmerülö dilemmákat az önálló, foglalkozásuk körében eljáró személyek fogyasztóként történő minősítése tárgyában. ${ }^{5}$

A hazai joggyakorlat részletesen vizsgálta mind a korábbi fogyasztóvédelemről szóló 1997. évi CLV. törvény, mind a régi Ptk. szabályai alapján a jogi személyek fogyasztói minőségét. A Legfelsőbb Bíróság BH2006. $343^{6}$ és EBH2004. $1093^{7}$ számú döntéseiben az Fgytv. szerinti fogyasztói minőség vizsgálatakor azt az álláspontot képviselte, mely szerint a fogyasztói státusz egyik legfontosabb kritériuma, hogy a dolog megszerzése, birtoklása, használata annak végsö felhasználása érdekében történjen. A Fővárosi Ítélőtábla 6.Pf.20.911/2008/7 számú ítéletében arra a következtetésre jutott, hogy a Ptk. alkalmazási körében, a fogyasztói szerződés meghatározása során, a régi Ptk. 685. \e) pontjának közvetlen tételes jogi rendelkezéséből kell kiindulni, amikor kizárólag az ügylet célja vizsgálandó a fogyasztói szerződés létrejöttének megállapítása szempontjából. A Legfelsőbb Bíróság az EBH 2005. 1321. szám alatt közzétett eseti döntésében a régi Ptk. 685. \$ d) pontjának alapul vételével olyan iránymutatást adott, hogy a szerződő fél csak akkor minősül fogyasztónak, ha a szerződést olyan célból köti meg, amely független az általa folytatott gazdasági, vagy szakmai tevékenységtől. Vékás Lajos álláspontja szerint, ${ }^{8}$ megegyezően a Ptk.

4 Lásd ezzel kapcsolatban: Hámori A.: A fogyasztóvédelem közigazgatási "útvesztői”: (a "fogyasztó" fogalom "dilemmái”). In: Majoros P. (szerk.): BGF Tudományos Évkönyv 2008: Kultúraközi párbeszéd az üzleti világban.

Budapesti Gazdasági Főiskola, Budapest, 2009. 150-166.; Papp T.: Mit takar a fogyasztó kategóriája? Céghirnök, 2013/2. 5., Fuglinszky Á.: Fogyasztói adásvétel, kellék- és termékszavatosság. Wolters Kluwer, Budapest, 2016. 27-50.

5 Funglinszky Á.: i. m., 39-50.

6 L. Legf. Bír. Kfv. III. 37.091/2004. sz.

7 L. Legf. Bír. Kfv. III. 37.675/2003. sz.

8 Vékás L.: Az európai közösségi magánjog sajátos alanyáról: a „fogyasztó” fogalmáról. Európai Jog, 2002/5. 4. 
fogyasztó fogalmának értelmezésével kapcsolatos joggyakorlattal, a szigorúbb jogvédelemre csak kivételes és indokolható esetben kerülhet sor, így az üzleti, gazdasági tevékenységgel bármilyen igazolható kapcsolat már ennek a kivételes elbánásnak a mellőzésével jár. A természetes személy minőségükben önálló gazdasági, szakmai tevékenységet végzők fogyasztói minősítése kapcsán azt kell vizsgálnunk, hogy a szerződéskötés a vállalkozás nevében eljáró személy saját vagy családja személyes szükségleteinek kielégítését szolgálta, vagy bármilyen formában kereskedelmi, üzleti, gazdasági célból történt. Ezt a gondolatmenetet támasztja alá az Európai Bíróság C-110/14. sz. Horaţiu Ovidiu Costea és SC Volksbank România SA ügyben hozott döntésének ${ }^{9}$ indokolása is, amelyben egy szakmailag hozzáértő ügyvéd mint hitelfelvevő szerepét értelmezte az Európai Bíróság egy olyan hitelügylettel kapcsolatban, ahol a jelzálogfedezetet az ügyvédi iroda ingatlana biztosította. A bíróság szerződésszegésen alapuló igény esetén is köteles hivatalból vizsgálni és értékelni a szerződés fogyasztói jellegét. ${ }^{10}$

Vállalkozásnak a Ptk. 8:1. \$(1) bekezdésének 4. pontja alapján a szakmája, önálló foglalkozása vagy üzleti tevékenysége körében eljáró személy minősül. A Ptk. 6:157. \$ (2) bekezdése átfogó jelleggel rögzíti, hogy a fogyasztó és vállalkozás közötti szerződésben semmis az a kikötés, amely a Ptk. XXIV. fejezetének a kellékszavatosságra és a jótállásra vonatkozó rendelkezéseitől a fogyasztó hátrányára tér el (klaudikáló kógens rendelkezések). A fogyasztó ténylegesen az 1999/44/EK irányelv által elvárt védett helyzetbe kerül, mert a hátrányára eltérő kikötés valójában nem köti.

\section{Szerződésszerüség és szerződésszegés}

\subsection{A szerződésszerüség követelménye}

A hazai szabályozásban a Ptk. normarendszerében több szinten, az általános kötelmi és az egyes szerződésekre vonatkozó speciális szabályok között is tetten érhető e követelmény. Generális jelleggel - az 1999/44/EK irányelv 2. cikk (1) bekezdése szerint - a Ptk. 6:34. § előírja, hogy a szolgáltatást a kötelem tartalmának megfelelően kell teljesíteni. Ahogy arra az 1/2012. (VI.21.) PK vélemény 1. pontjához füzött indokolás is utal, a felek szerződésükben szabadon

9 C-110/14. sz. Horațiu Ovidiu Costea v. SC Volksbank România SA ügyben 2015. szeptember 3-án hozott ítélet (ECLI:EU:C:2015:538)

10 Fővárosi Ítélőtábla 6.Pf.21.974/2012/10. 
meghatározhatják a kötelezett által nyújtandó szolgáltatás minőségét, konkrét tulajdonságait, azaz a szerződéses minőségi követelményeket. A szolgáltatás minőségének megítélése során ezért alapvetően a szerződésben meghatározott követelményekből kell kiindulni. ${ }^{11}$

Az irányelv 2. cikkének (2) bekezdésében meghatározott, a fogyasztási cikk szerződésszerűségének vélelmére vonatkozó rendelkezések a Ptk. 6:123. \$ (1) bekezdésében, a szerződés teljesítésére vonatkozó szolgáltatás-minőségi szabályok között jelennek meg. Az irányelv 2. cikkének (2) bekezdésétől eltér a Ptk. szöveghasználata, hiszen a Ptk. hivatkozott rendelkezései nem csak az irányelvi definíció szerinti fogyasztási cikkekre, hanem a szolgáltatások átfogó körére vonatkoznak, illetve kiegészül a jogszabályi követelményekre vonatkozó ponttal.

A szolgáltatásnak a teljesítés időpontjában alkalmasnak kell lennie a rendeltetése szerinti célra, így:

- alkalmasnak kell lennie a jogosult által meghatározott célra, ha azt a jogosult a szerződéskötés előtt a kötelezett tudomására hozta,

- alkalmasnak kell lennie azokra a célokra, amelyekre más, azonos rendeltetésű szolgáltatásokat rendszerint használnak,

- rendelkeznie kell azzal a minőséggel, és nyújtania kell azt a teljesítményt, amely azonos rendeltetésű szolgáltatásoknál szokásos, és amelyet a jogosult elvárhat, figyelembe véve a kötelezettnek vagy - ha nem a kötelezett állítja elő a szolgáltatás tárgyát - a szolgáltatás előállítójának és ezek képviselőjének a szolgáltatás konkrét tulajdonságaira vonatkozó nyilvános kijelentését,

- rendelkeznie kell a kötelezett által adott leírásban szereplő vagy az általa a jogosultnak mintaként bemutatott szolgáltatásra jellemző tulajdonságokkal,

- meg kell felelnie a jogszabályban meghatározott minőségi követelményeknek.

Az 1999/44/EK irányelv 2. cikk (4) bekezdését átültetése a Ptk. 6:123. \$ (2) bekezdése ültette át a magyar jogrendszerbe. A nyilvános kijelentéseknek való megfelelés követelménye tekintetében kimentési bizonyításra ad ez a rendelkezés lehetőséget, a következő kivételek rögzítésével:

- a nyilvános kijelentést a kötelezett nem ismerte, és azt nem is kellett ismernie;

11 Kúria Pfv.V.21.825/2012/9. 
- a nyilvános kijelentést a szerződéskötés időpontjáig már megfelelő módon helyesbítették;

- a nyilvános kijelentés a jogosult szerződéskötési elhatározását nem befolyásolhatta.

A szerződéses minőségi követelményeknek való megfelelés esetében a szolgáltatott dolog törvényes tulajdonságait meghatározó jogi szabályozás is irányadó. Ez magában foglalja egyrészt a teljesítés minőségére vonatkozó, a Ptk. 6:123. \$ (1) bekezdésében foglalt általános szabályokat (generálklauzula), a dolog (termék, szolgáltatás) konkrét tulajdonságaira vonatkozó minőségi követelményeket rögzítő szabványokat, műszaki előírásokat, szakmai útmutatókat előíró jogszabályokat; valamint a dologhoz kapcsolódó járulékos kötelezettségeket szabályozó normákat egyaránt. A hibás teljesítés megítélése során e körben egyébként a generálklauzula követelményéből kell kiindulni. A Ptk. 6:123. $₫$ (4) bekezdése új szabályként rögzíti a rendeltetés szerinti célra való alkalmasság szempontjából a minőségi előírások figyelembevételének szükségességét is. A Ptk. 6:124. \$-ában meghatározottak szerint a kötelezett köteles a jogosultnak átadni a szolgáltatásról szóló tájékoztató leírásokat és egyéb dokumentumokat is. Ennek elmulasztása szintén a szolgáltatás hibáját eredményezi, még akkor is, ha maga a föszolgáltatás egyébként nem minőséghibás.

\subsection{A hibás teljesítés}

Dogmatikai oldalról megközelítve maga a hibás teljesítés a szerződésszegés egyik esetköre. A Ptk. 6:137. \$-a szerint a szerződés megszegését jelenti bármely kötelezettség szerződésszerű teljesítésének elmaradása. A szerződésszegés általános jogkövetkezményei a teljesítés követelése, a visszatartási jog gyakorlása, az elállás, illetve felmondás, valamint a kártérítés.

A Ptk. 6:157. \$ (1) bekezdése szerint a kötelezett hibásan teljesít, ha a szolgáltatás a teljesítés időpontjában nem felel meg a szerződésben, vagy jogszabályban megállapított minőségi követelményeknek. A hibás teljesítés Ptk. által meghatározott jogkövetkezménye a jog- és kellékszavatosság, a hasonló jogi alapokon nyugvó, de összességében szigorúbb felelősséget teremtő jótállás, a kötelmi viszonyok zárt jellegét áttörő termékszavatosság, valamint a kártérítés. 


\subsection{A jogosult által ismert hiba}

Az 1999/44/EK irányelv 2. cikk (3) bekezdésének megfelelő módon a Ptk. 6:157. $\$(1)$ bekezdése is rögzíti, hogy nem teljesít hibásan a kötelezett, ha a jogosult a hibát a szerződéskötés időpontjában ismerte, vagy a hibát a szerződéskötés időpontjában ismernie kellett, azaz a hiba nem ún. rejtett hiba. Ahogyan az 1/2012. (VI.21.) PK vélemény 2. pontja is utal rá, ekkor a kötelezett hibás teljesítése nem állapítható meg és nem a hibás teljesítés alóli mentesülési okként határozza ezt meg, hiszen ebben az esetben a kötelezett a szerződésben foglaltaknak megfelelően teljesít. ${ }^{12}$

Felismerhető hibának az ún. nyílt, tehát az egyszerủ észleléssel megállapítható hibák minősülnek, továbbá azok a hibák, amelyeket a jogosultnak a kötelezett tájékoztatása, a szerződéskötés körülményei, illetőleg a dolog életkora, állapota és használtsági foka alapján egyébként számításba kell vennie, valamint azok a hibák is, amelyek fennállása, illetve jelentkezése a ténylegesen ismert, illetve a nyílt hibákra tekintettel a szerződéskötéskor alappal feltételezhető, előrelátható. ${ }^{13}$ Önmagában egyébként bizonyos hibajelenségek észlelése esetén sem várható el a laikus vevőtől, hogy ebből műszaki szakértelmet igénylő olyan következtetésre jusson, hogy a teljesítés hibás. ${ }^{14}$

A használt dolog esetében hibás teljesítés viszont csak akkor állapítható meg, ha a hiba független a használtságtól, illetőleg az az elhasználódás számítható mértékét túllépi, $s$ a rendeltetésszerü használatot lehetetlenné teszi. ${ }^{15}$

\subsection{A bizonyítási teher általános szabálya és a hibás teljesítési vélelem}

APtk.6:158. \által meghatározott, fogyasztó és vállalkozásközöttiszerződésesetén a hibás teljesítési vélelmére vonatkozó szabályok tartalmilag megfeleltethetők az 1999/44/EK irányelv 5. cikk (3) bekezdésében foglaltaknak. A hatályos jogszabályhely alapján a fogyasztó és vállalkozás közötti szerződés esetén az ellenkező bizonyításáig vélelmezni kell, hogy a teljesítést követő hat hónapon belül a fogyasztó által felismert hiba már a teljesítés időpontjában megvolt.

12 Kúria Pfv.IV.20.366/2014/5.

13 Kúria Pfv.V.21.203/2012/6.

14 Kúria Pfv.V.21.083/2012/6.

15 Szegedi Ítélőtábla Pf.II.20.445/2014/3. 


\section{A szavatossági és jótállási igények érvényesíthetőségének szabályai}

\subsection{Kellékszavatosság}

A Ptk. 6:159. \$ (1) bekezdése szerint olyan szerződés alapján, amelyben a felek kölcsönös szolgáltatásokkal tartoznak, a kötelezett a hibás teljesítésért kellékszavatossággal tartozik. Lényeges, hogy a szavatossági felelősség a szerződés hibás teljesítésének jogkövetkezménye, ezért szavatossági igény kizárólag szerződéses jogviszonyban érvényesíthető. ${ }^{16}$

\subsection{A kellékszavatossági jogok érvényesítésének rendszere}

A Ptk. 6:159. \$ szerinti kellékszavatossági jogok szabályozásának alapját az 1999/44/EK irányelv 3. cikkében meghatározott szabályok adják, ${ }^{17}$ ugyanakkor a Ptk. átveszi a régi Ptk. 306. \$ (3) bekezdésében foglalt szabályt is, amely szerint a hibát a kötelezett költségére a jogosult maga is kijavíthatja vagy mással kijavíttathatja, valamint az irányelvi szabályozást a második sorban érvényesíthető igények vonatkozásában az érdekmúlásra vonatkozó rendelkezésekkel kibővíti. Mindezek tükrében a törvény a szavatossági jogok érvényesítését továbbra is ún. kétlépcsős rendszerben képzeli el, vagyis rangsort állít fel közöttük. Első lépcsőben a Ptk. 6:159. $\$(2)$ bekezdésének a) pontjában a kijavítást vagy kicserélést, míg b) pontjában a második lépcsőben az ellenszolgáltatás arányos leszállítását, kötelezett költségére történő kijavítást vagy kijavíttatást, valamint az elállás jogát nevesíti.

A kellékszavatossági jogok érvényesítése során fokozott jelentősége van az arányossági elv érvényesülésének. Az arányosság elve explicit módon megjelenik az első sorban érvényesíthető kellékszavatossági jogok vonatkozásában, miként a Ptk. 6:159. \$ (2) bekezdésének a) pontja a jogosult választását korlátozza a kijavítás és kicserélés között akkor, ha a választott kellékszavatossági jog teljesítése lehetetlen, vagy ha az a kötelezettnek - másik kellékszavatossági igény teljesítésével összehasonlítva - aránytalan többletköltséget eredményezne, figyelembe véve a szolgáltatás hibátlan állapotban képviselt értékét, a szerződésszegés súlyát és a kellékszavatossági jog teljesítésével a jogosultnak okozott érdeksérelmet. Az arányossági feltétel teljesülését az eltérő lépcsőkbe tartozó jogok közötti választás

16 Szegedi Ítélőtábla Pf.II.20.049/2013/3.

17 A régi Ptk. normaszövegében a 306. \$szabályozta a kellékszavatossági jogokat. 
során is vizsgálni kell. Ennek megfelelően nem kérhet például kijavítást a jogosult akkor, ha ez a kötelezettnek az árleszállításhoz képest aránytalan többletköltséget eredményezne. ${ }^{18}$

Egységes a bírói gyakorlat abban, hogy ha a szolgáltatott dolog valamely hibáját több hónap alattsem tudják ered ményesen kijavítani, ennek eredményeként sérül a jogosultnak a folyamatos használathoz való érdeke, amely megalapozza a kicserélés iránti igényt. ${ }^{19} \mathrm{Az}$ arányosság elvével összeegyeztethető továbbá, hogy a jogosult a kijavítás mellett is igényt tarthat árleszállításra, ha a szolgáltatás értéke és ellenértéke közötti egyensúly csak így állítható helyre. Előfordulhat ugyanis például, hogy a dologban a javítás elvégzése után is fennmarad olyan hiba, amely a rendeltetésszerű használatra való alkalmasságát, az élettartamát, vagy az értékét csökkenti, illetve hátrányosan befolyásolja a küllemét, az esztétikai hatását, viszont a jogosult a szolgáltatáshoz ilyenkor is ragaszkodik. ${ }^{20}$ Újdonság, hogy a dolog kicserélése esetén az értéknövekedés miatti gazdagodás jogosult általi megtérítését nem lehet követelni a fogyasztó és vállalkozás közötti szerződésben.

Fontos megjegyezni ugyanakkor, hogy - miként az 1/2012. (VI.21.) PK vélemény 3. pontjából és annak indokolásából is kiderül - az ún. második lépcsőbe tartozó szavatossági jogok érvényesítésének nem szükségképpeni előfeltétele az, hogy a jogosult előzetesen eredménytelenül felhívja a kötelezettet a dolog kijavításáravagy kicserélésére. Ajogosultugyanis ilyen előzetes felhíváshiányában is bizonyíthatja, hogy a kötelezett a kijavítás vagy a kicserélés kötelezettségének a dolog tulajdonságaira és a jogosult által elvárható rendeltetésére figyelemmel megfelelő határidőn belül, a jogosult érdekeit figyelembe véve nem tud eleget tenni, és erre tekintettel megalapozottan tarthat igényt a kijavítási költség megfizetésére vagy az ellenszolgáltatás arányos leszállítására, illetve elállhat a szerződéstől. Egyébként az, ha a kötelezett magának a hibás teljesítésnek a tényét is vitatja, ez általában - külön felhívás hiányában is - azt jelenti, hogy a kijavítást, kicserélést sem vállalja.

Külön kiemelést érdemel továbbá az érdekmúlás kérdésköre. Az érdekmúlás szempontjából nem azt kell bizonyítani, hogy általában a teljesítés befejezése már nem áll a jogosult érdekében (abszolút érdekmúlás), hanem azt, hogy a kötelezett részéről (relatíve) megvalósuló további teljesítéshez füződő érdek szűnt meg. ${ }^{21}$

18 1/2012. (VI.21.) PK vélemény 4. pontja és az ahhoz füzött indokolás

19 Szegedi Ítélőtábla Gf.I.30.253/2013/2.

20 1/2012. (VI.21.) PK vélemény 7. pontjához füzött indokolás

21 Szegedi Ítélőtábla Gf.I.30.039/2011/3. 
A bírói gyakorlat eddig is jogszerünek tekintette a jogosult szerződéstől való elállását, amennyiben a szerződés tárgyát képező új dolog rövid időközönként többször is meghibásodott, függetlenül attól, ha a kötelezett a hibákat mindig kijavította. ${ }^{22}$

A bírói gyakorlat szerint az ellenszolgáltatás arányos leszállítása (jellemzően árleszállítás) rendeltetése a szolgáltatás és az ellenszolgáltatás közötti, a hibás teljesítés folytán megbomlott értékegyensúly helyreállítása, melynek meghatározása során az ellenszolgáltatásból kell kiindulni. ${ }^{23}$ Azonban nem a dolog forgalmi értékéből, hanem az érvényes szerződésből, a kikötött vételárból kiindulva kell azt vizsgálni, hogy a dolog szavatossági hibái milyen mértékben sértik a jogosultnak a hibátlan teljesítéshez füződő érdekét, és ez az érdeksérelem a szerződésben kikötött vételár milyen összegű csökkentésével orvosolható.

A kijavítási költség megfizetése az ún. első lépcsős szavatossági jogok közül kizárólag a kijavítás helyett választható. A jogosult kijavítási költség megtérítése iránti igényt érvényesíthet akkor is, ha a hibás teljesítés körülményei, illetve a kötelezett magatartása miatt alappal rendül meg a bizalma abban, hogy a kötelezett a javítást az ő méltányos érdekeinek sérelme nélkül, megfelelő határidőn belül el tudja végezni. ${ }^{24} \mathrm{Az}$ egységes bírósági gyakorlat szerint a kijavítási költség iránti igény érvényesítésének nem előfeltétele a kijavítás elvégzése.

Az 1999/44/EK irányelv 3. cikk (2) bekezdésében foglaltaknak megfelelően a fogyasztó a választott kellékszavatossági jogról másikra térhet át. A Ptk. 6:160. \-ában foglaltrendelkezések az áttérés esetén a jogosult terhére róják az ezzel okozott költségek kötelezettnek való megfizetését. Ez alól kivételt jelent, ha az áttérésre a kötelezett magatartása adott okot, vagy az áttérés egyébként indokolt volt. Az áttérésre a kötelezett magatartása ad okot például azzal, hogy a jogosult hibabejelentésére nem reagál, a neki megküldött hibalistában szereplő hibákat nem vizsgálja, nem javítja. ${ }^{25}$

$\mathrm{Az}$ arányosság követelménye implicit módon a második sorban érvényesíthető kellékszavatossági jogok vonatkozásában is megjelenik, ugyanis a Ptk. 6:159. \$ (3) bekezdése rögzíti, hogy jelentéktelen hiba miatt elállásnak nincs helye. A jogosult elállása esetén egyébként a szerződés a megkötésének időpontjára visszamenő hatállyal szűnik meg, és a már teljesített szolgáltatások

22 Győri Ítélőtábla Pf.II.20.271/2013/8.

23 Győri Ítélőtábla Gf.II.20.099/2009/13.

24 1/2012. (VI.21.) PK vélemény 8. pontja és annak indokolása

25 Fővárosi Ítélőtábla 3.Pf.21.536/2009/5. 
visszajárnak, a kölcsönösen teljesített szolgáltatások visszatérítése föszabályként pedig csak kölcsönösen és egyidejüleg történhet. ${ }^{26}$ Erre tekintettel - ahogyan azt az 1/2012. (VI.21.) PK vélemény 9. pontja is rögzíti - nem gyakorolhat elállást mint szavatossági jogot a jogosult akkor, ha a dolgot nem hajlandó visszaszolgáltatni. A kötelezett utólagos, az elállás közlését követő intézkedései, nyilatkozatai ugyanakkor az elállás megalapozottságát nem befolyásolhatják.

A Ptk. 6:167. \$ (2) bekezdése alapján kicserélés, vagy elállás esetén a jogosult nem köteles a dolognak azt az értékcsökkenését megtéríteni, amely a rendeltetésszerü használat következménye. Sőt nem akadálya az elállási jog gyakorlásának az sem, ha a jogosult a dolgot a hibás teljesítés miatt vagy a kötelezett érdekkörébe tartozó bármely más okból csak lényegesen értékcsökkent állapotban vagy egyáltalán nem tudja visszaszolgáltatni. ${ }^{27}$ Végül pedig kiemelendő, hogy az arányosság szempontjának a második lépcsőbe tartozó szavatossági jogok közötti választás során is érvényesülnie kell, így például kijavítási költség címén nem követelhető aránytalanul nagyobb összeg annál, ami az ellenszolgáltatás arányos leszállítása címén megállapítható lenne és fordítva.

\section{Határidők a hibás teljesítés szabályozásában}

\subsection{A hiba közlése, az érvényesített szavatossági igény terjedelme}

Az 1999/44/EK irányelv 5. cikkének (2) bekezdése által adott lehetőséggel élve a Ptk. 6:162. \$ (1)-(2) bekezdései rögzítik, hogy a jogosult a hiba felfedezése után késedelem nélkül köteles a hibát a kötelezettel közölni. A fogyasztó és vállalkozás közötti szerződés esetén a hiba felfedezésétől számított 2 hónapon belül közölt hibát kell késedelem nélkül közöltnek tekinteni. Jogkövetkezményeit tekintve a késedelem, bár jogvesztéssel nem jár egyébként, a Ptk. 6:162. \$ (3) bekezdése rögzíti, hogy a közlés késedelméből eredő kárért a jogosult felelős.

\subsection{A kellékszavatossági igény elévülése}

A Ptk. 6:21. \$-ának rendelkezéseire tekintettel, ha a jogszabályban előírt határidő nem jogvesztő, arra az elévülés szabályait kell alkalmazni. A kellékszavatossági

26 A felperesnek az elállásra alapított keresete ekként megalapozza a bíróságnak azt a kötelezettségét is, hogy az alperes ellenkérelme vagy viszontkeresete hiányában is döntsön az alperes részére visszajáró szolgáltatásról.

27 1/2012. (VI.21.) PK vélemény 9. pontja 
igények elévülési ideje általánosságban a Ptk. 6:163. \$ (1) bekezdése alapján egy év, de a Ptk. több esetben is speciális elévülési határidőt állapít meg, ${ }^{28}$ így

- fogyasztó és vállalkozás közötti szerződés esetén a fogyasztó kellékszavatossági igénye a teljesítés időpontjától számított két év alatt évül el; azzal, hogy ha a szerződés tárgya használt dolog, a felek rövidebb elévülési időben is megállapodhatnak, azonban egy évnél rövidebb elévülési határidő ebben az esetben sem köthető ki érvényesen;

- ha a szerződés alapján szolgáltatott dolog ingatlan, a kellékszavatossági igény a teljesítés időpontjától számított öt év alatt évül el.

Az elévülés jogkövetkezménye a Ptk. 6:23. $\$(1)$ bekezdése tükrében az, hogy az elévült követelést bírósági eljárásban nem lehet érvényesíteni, ezt azonban hivatalból nem kell figyelembe venni.

A kellékszavatossági elévülési határidők számítására az elévülés általános szabályai az irányadók, ${ }^{29}$ így megfelelően alkalmazni kell a Ptk. 6:24. elévülés nyugvására és a 6:25. \$ elévülés megszakítására vonatkozó szabályait is. A Ptk. 6:24. $\$$ (1) bekezdése szerint, ha a követelést a jogosult menthető okból nem tudja érvényesíteni, az elévülés nyugszik. A Ptk. 6:24. \$(2) bekezdése szerint pedig, ha az elévülés nyugszik, az akadály megszünésétől számított egyéves - egyéves vagy ennél rövidebb elévülési idő esetén három hónapos - határidőn belül a követelés akkor is érvényesíthető, ha az elévülési idő már eltelt, vagy abból egy évnél egyéves vagy ennél rövidebb elévülési idő esetén három hónapnál - kevesebb van hátra.

$\mathrm{Az}$ 1/2012. (VI.21.) PK vélemény 11. pontjához füzött indokolás szerint egyébként a hiba felismerését az jelenti, ha a jogosult tudomást szerez mindazokról a hibával kapcsolatos tényekről, amelyek ismerete szükséges a hiba miatti szavatossági igény érvényesítéséhez, vagyis a hibajelenség észlelése mellett felismeri a hiba okát, terjedelmét, jelentőségét és következményeit is. Az elévülés nyugvásának megszűnése ugyanis csak akkor következhet be, ha a jogosult a követelése érvényesíthetőségének helyzetébe került. Az azonban, hogy a jogosult a hibát nem ismerte fel, csak akkor eredményezheti az elévülés nyugvását, ha a hiba kellő időben történő felismerése menthető, vagyis a jogosult hibáján kívüli okból maradt el.

28 Ptk. 6:163. \$(1)-(2) bekezdései, a régi Ptk. normaszövegében

29 1/2012. (VI.21.) PK vélemény 11. pontjához füzött indokolás 
A Ptk. 6:163. \$ (4)-(5) bekezdései a kellékszavatossági igények elévülésének szabályozása körében egyes speciális szabályokat is meghatároznak, így

- nem számít bele az elévülési időbe a kijavítási időnek az a része, amely alatt a jogosult a dolgot rendeltetésszerüen nem tudja használni,

- a dolognak a kicseréléssel, vagy kijavítással érintett részére a kellékszavatossági igény elévülése újból kezdődik; ezt a szabályt kell alkalmazni arra az esetre is, ha a kijavítás következményeként új hiba keletkezik.

\subsection{Költségviselés}

Az 1999/44/EK irányelv 3. cikkének (4) bekezdése leszögezi, hogy a „térítésmentesség” fogalma magában foglalja a fogyasztási cikk szerződésszerü állapota helyreállításának szükséges költségeit, különösen a postaköltséget, a munkadíjat és az anyagköltséget. Ezzel összhangban a Ptk. 6:166. \$ (1) bekezdése is rögzíti, hogy a szavatossági kötelezettség teljesítésével kapcsolatos költségek a kötelezettet terhelik, amely alól kivételt jelent a Ptk. 6:166. \$ (2) bekezdésének szabálya, amely szerint, ha a dolog meghibásodásában a jogosultat terhelő karbantartási kötelezettség elmulasztása is közrehatott, a szavatossági kötelezettség teljesítésével felmerült költségeket közrehatása arányában a jogosult köteles viselni. Ennek azonban további törvényi feltétele az is, hogy a dolog karbantartására vonatkozó ismeretekkel a jogosult rendelkezzen, vagy a kötelezett e tekintetben tájékoztatási kötelezettségének eleget tegyen.

\section{Jótállás}

\subsection{A jótállás szabályai a Ptk. normaszövegében}

A Ptk. normaszövegében a jótállás a hibás teljesítés jogkövetkezményeként került meghatározásra. A Ptk. 6:171. \$ (1) bekezdése alapján a kötelezett a jótállás időtartama alatt a jótállást keletkeztető jognyilatkozatban ${ }^{30}$ vagy jogszabályban foglalt feltételek szerint köteles helytállni a hibás teljesítésért. Mentesül a jótállási kötelezettség alól, ha bizonyítja, hogy a hiba oka a teljesítés után keletkezett. Ilyenkor tehát a kötelezettnek kell kimentenie magát annak bizonyításával, hogy

30 Az 1999/44/EK irányelv 6. cikk (1) bekezdésével összhangban, azzal, hogy nem tartalmaz a kapcsolódó reklámban meghatározott feltételekre utalást. 
a hiba oka a teljesítés után keletkezett. ${ }^{31} \mathrm{Ha}$ a bizonyítás ebben a körben - akár azért, mert a beszerzett bizonyítékok alapján az derül ki, hogy a szolgáltatásban a hiba már a teljesítéskor is megvolt, akár azért, mert nem lehet egyértelműen megállapítani, hogy a hibát mi idézte elö, illetve, hogy a hiba oka mikor keletkezett - nem vezet eredményre, a kötelezett a jótállási helytállás alól nem mentesülhet. ${ }^{32}$

A Ptk. 6:171. $\$(2)$ bekezdésében jogszabályi előírásként is kifejezésre jut, hogy a jótállás a jogosultnak jogszabályból eredő jogait nem érinti. A Ptk. 6:172. \$ rendelkezés szerint a jótállásból eredő jogokat a dolog tulajdonjogának átruházása esetén az új tulajdonos érvényesítheti a jótállást vállaló kötelezettel szemben (ezt a régi Ptk. nem tartalmazta).

A szigorú felelősségi alakzat miatt a jótállási idő - föszabály szerint - jogvesztő jellegü. ${ }^{33} \mathrm{Ez}$ azt jelenti, hogy a kötelezett kizárólag azokért a hibákért, rendellenességekért áll helyt jótállási alapon, amelyek a jótállási idő letelte előtt keletkeztek és a jogosult emiatt igényét bejelentette. Ennek megfelelően a jótállási idő - a jogszabályi esetektől eltekintve - nem nyugszik és nem szakad meg akkor sem, ha a hiba a jótállási idő alatt nem vált felismerhetővé. ${ }^{34}$ Habár a jótállási határidő elmulasztása a Ptk. 6:173. $\$$ (1) bekezdése alapján jogvesztéssel jár, azonban ez nem zárja ki a hibás teljesítés egyéb jogkövetkezményeinek érvényesítését és fontos kiemelni, hogy ha a jótállásra kötelezett kötelezettségének a jogosult felhívására - megfelelő határidőben - nem tesz eleget, a jótállási igény a felhívásban tűzött határidő elteltétől számított három hónapon belül akkor is érvényesíthető bíróság előtt, ha a jótállási idő már eltelt.

A Ptk. 6:173. $\$(2)$ bekezdése szerint a jótállási igény érvényesítésére egyebekben a kellékszavatossági jogok gyakorlására vonatkozó szabályokat kell megfelelően alkalmazni. Megjegyzendő ezen szabállyal összefüggésben, hogy

- a jótállási idő alatt felmerült hiba miatt szavatosság, illetve kártérítés címén érvényesített igényeket a szavatosságra, illetve a kártérítésre vonatkozó szabályok alapján kell elbírálni, 
- a hibás teljesítéssel okozott következménykárokra a jótállási kötelezettség - jogszabály eltérő rendelkezése, illetve erre vonatkozó külön szerződéses kötelezettségvállalás hiányában - nem terjed ki, mivel ezek a jótállással alapvetően védeni kívánt vagyoni érdek körén kívül esnek. ${ }^{35}$

\subsection{Jogszabályon alapuló kötelező jótállás szabályai}

A Ptk. 6:171. \$ (1) bekezdése is utal rá, hogy jótállási kötelezettség jogszabályon is alapulhat. A jótállás szabályozása kapcsán utóbbira példaként megemlíthető az egyes tartós fogyasztási cikkekre vonatkozó kötelező jótállásról szóló 151/2003. (IX. 22.) Korm. rendelet (a továbbiakban: Korm. rendelet I.), a lakásépítéssel kapcsolatos kötelező jótállásról szóló 181/2003. (XI. 5.) Korm. rendelet (a továbbiakban: Korm. rendelet II.), valamint az egyes javítókarbantartószolgáltatásokra vonatkozó kötelező jótállásról szóló 249/2004. (VIII. 27.) Korm. rendelet (a továbbiakban: Korm. rendelet III.) egyaránt. A Kormány a Korm. rendelet I. és II. módosítását 2020. július 12-én hirdette ki, melyek 2021. január 1-től alkalmazandók. ${ }^{36}$

A Korm. rendelet I. 1. \$ (1) bekezdése rögzíti, hogy a Polgári Törvénykönyv szerinti fogyasztó és vállalkozás közötti szerződés keretében eladott, a Korm. rendelet I. 1. mellékletben felsorolt új tartós fogyasztási cikkekre e rendelet szabályai szerint jótállási kötelezettség terjed ki. Garanciális jelentőségű szabály a Korm. rendelet I. 1. $\$(5)$ bekezdése, miszerint a fogyasztó és vállalkozás közötti szerződésben semmis az a kikötés, amely e rendelet rendelkezéseitől a fogyasztó hátrányára tér el.

A kötelező jótállás alanyi köre tekintetében a Korm. rendelet I. 1. $₫(2)$ bekezdése rögzíti, hogy a jótállási kötelezettség azt a vállalkozást terheli, amelyet a fogyasztóval kötött szerződés a szerződés tárgyát képező szolgáltatás nyújtására kötelez, míg a jogosult a fogyasztási cikk fogyasztónak minősülő tulajdonosa lehet. ${ }^{37}$ A kötelező jótállás szigorú szabályai vonatkozásában eltérést a Korm. rendelet I. két esetben enged meg csupán:

35 1/2012. (VI.21.) PK vélemény 15. pontja és ahhoz füzött indokolás

36 A Kormány 270/2020. (VI. 12.) Korm. rendelete az egyes tartós fogyasztási cikkekre vonatkozó kötelező jótállásról szóló 151/2003. (IX. 22.) Korm. rendelet, valamint az egyes javító-karbantartó szolgáltatásokra vonatkozó kötelező jótállásról szóló 249/2004. (VIII. 27.) Korm. rendelet módosításáról

37 Ez utóbbi egyébként - észszerủ szűkítés mellett - összhangban van a Ptk. 6:172. \$-ában meghatározott szabályokkal. 
- a fogyasztó számára terhesebb irányba, miként az 1. \$(3) bekezdésében meghatározottakra tekintettel a jótállás érvényességéhez, valamint a jótállásból eredő jogok érvényesítéséhez a vállalkozás további követelményt támaszthat a fogyasztóval szemben, ha a fogyasztási cikk megfelelö üzembe helyezése más módon nem biztosítható és a követelmény teljesítése nem jelent aránytalan terhet a fogyasztó számára,

- fogyasztó számára kedvezőbb irányba, mivel az 1. \$(4) bekezdése alapján, ha a gyártó a fogyasztási cikkre az e rendeletben foglaltaknál kedvezőbb jótállási feltételeket vállal, a jótállás alapján a vállalkozást megillető jogok a fogyasztó és vállalkozás közötti szerződés teljesítésének időpontjában átszállnak a fogyasztóra.

A joggyakorlat rámutatott arra, hogy nincs elzárva a jótállásra kötelezett attól, hogy a jótállási kötelezettségét csak az általa megjelölt szakszervizek közreműködésével történt üzembe helyezés esetén vállalja. Az ilyen feltétel (kikötés) azonban nem jelenthet aránytalan terhet a fogyasztóra. A jótállás kötelezettjének kell ugyanakkor bizonyítania, hogy az üzembe helyezés egy szakszerviz szolgáltatásának igénybevételét nélkülözhetetlenné teszi. ${ }^{38}$

A Ptk. 6:173. $\$(1)$ bekezdésére figyelemmel a Korm. rendelet I. 2. $\$(1)-(2)$ bekezdései szerint a jótállás határideje a fogyasztási cikk fogyasztó részére történő átadásától, vagy ha az üzembe helyezést a vállalkozás vagy annak megbízottja végzi, az üzembe helyezés napjától számított egy év. ${ }^{39}$

A jótállásból eredő jogok a jótállási jeggyel érvényesíthetőek, ${ }^{40}$ és ellentétben a kellékszavatossággal, ebben az esetben a vásárlásról készült számla bemutatása nem kötelező. Az 1999/44/EK irányelv 6. cikk (3) bekezdésére figyelemmel a Korm. rendelt I. 3. $\$(1)$ bekezdése is rögzíti, hogy a vállalkozás köteles a fogyasztási cikkel együtt a jótállási jegyet a fogyasztó rendelkezésére bocsátani olyan formában, amely a jótállási határidő végéig biztosítja a jótállási jegy tartalmának jól olvashatóságát.

Az irányelv 6. cikk (4) bekezdésének megfelelően a Korm. rendelet I. 3. \$ (2) bekezdésében a magyar jogalkotó előírja, hogy a jótállási jegyet magyar nyelven

38 Kúria Pfv.VII.20.194/2012/6.

39 A jótállási határidő jogvesztő, de természetesen ez nem zárja ki a Ptk. szerinti kellékszavatossági jogok elévülési határidőben történő érvényesítését

40 Korm. rendelet I. 4. \$ (1) bekezdése 
kell megfogalmazni. Az irányelv 6. cikk (2) bekezdésével összhangban a Korm. rendelet I. 3. $\$(2)-(4)$ bekezdései tartalmazzák, hogy a jótállási jegyet milyen formában és milyen tartalommal kell kiállítani (közérthetően és egyértelműen, tartalmazza a felek adatait, szerződés teljesítésének adatait, átadás, üzembehelyezés határidejét, a fogyasztó jogérvényesítési lehetőségeiről szóló kitanítást).

A jótállási jegy közérthető módon és egyértelműen történő megfogalmazásának követelményével kapcsolatban a joggyakorlat rámutatott, hogy - a fogyasztókkal szembeni tisztességtelen kereskedelmi gyakorlat tilalmáról szóló 2008. évi XLVII. törvény 3. \$ (1) és (3) bekezdésére, 6 . $\$$ (1) bekezdés i) pontjára figyelemmel - a jótállási jegyen szereplő mondat megtévesztő, ha azt a képzetet kelti a fogyasztóban, hogy jótállási igényt csak akkor érvényesíthet, ha rendelkezik a jótállási jeggyel és a vásárlási okmányokkal. Megtévesztő továbbá a tájékoztatás, amely azt sugallja a vevőknek, hogy kizárják a jótállást az egész termékre vonatkozóan, ha abba nem eredeti gyári tartozék kerül, vagy azt nem szakszervizben javítják, vagy olyan károsodásra, ami nem eredeti kiegészítő készülék és tartozék használatából adódik. ${ }^{41}$

A Ptk. 6:171. \$ (1) bekezdésére tekintettel a vállalkozás a kormányrendeletben foglalt feltételek szerint köteles helytállni a hibás teljesítésért. A Korm. rendelet I. 5. $\$(1)-(3)$ bekezdései a fogyasztó kijavítási és kicserélési igényével kapcsolatban számos speciális szabályt tartalmaznak, mint például a fogyasztó igényét a jótállási jegyen feltüntetett javítószolgálatnál közvetlenül is érvényesítheti; a kijavítás során a fogyasztási cikkbe csak új alkatrész kerülhet beépítésre.

Szükséges külön kiemelni a Korm. rendelet I. 7. \$-ában foglalt garanciális jelentőségü szabályt, amely szerint, ha a fogyasztó a fogyasztási cikk meghibásodása miatt a vásárlástól (üzembe helyezéstől) számított három munkanapon belül érvényesít csereigényt, a vállalkozás nem hivatkozhat a Ptk. 6:159. \$(2) bekezdés a) pontja értelmében aránytalan többletköltségre, hanem köteles a fogyasztási cikket kicserélni, feltéve, hogy a meghibásodás a rendeltetésszerü használatot akadályozza. Amennyiben van ugyanolyan árucikk a forgalmazónál, előzetes vizsgálat nélkül azonnal köteles kicserélni a terméket, ha az azonnali csere azért nem lehetséges, mert a fogyasztási cikk átmenetileg nincs a forgalmazó üzletében vagy raktárában, akkor törekednie kell a tizenöt napon belüli cserére. ${ }^{42}$

A Korm. rendelet II. is kötelező jótállásra vonatkozó szabályokat határoz meg. Kötelező jótállás vonatkozik - a Korm. rendelet II. mellékleteiben

41 Kúria Kfv.III.37.038/2013/4.

42 Legfelsőbb Bíróság Kfv.III.37.027/2007/4. 
meghatározott körben - az újonnan épített lakásoknak, lakóépületeknek, közhasználatú építményeknek egyes épületszerkezeteire, egyes lakás- és épületberendezésekre, amennyiben azok a lakás alkotórészének minősülnek, továbbá ezek beépítésére, illetve beszerelésére, valamint a lakóépületeknek egyes, a lakásokat kiszolgáló helyiségeire és részeire is. Mindezek mellett pedig a jótállási kötelezettség kiterjed az újonnan épített lakásoknak, lakóépületeknek, közhasználatú építmények épületszerkezetei létrehozásánál felhasznált egyes termékeire és anyagaira. Nem áll fenn tehát ex lege a jótállási kötelezettség a használt ingatlan vásárlása esetén, így például, ha a használatba vételi engedélyt már korábban kiadták és az ingatlant ténylegesen használatba is vették. Természetesen ettől függetlenül szerződéssel jótállás önként még vállalható. ${ }^{43}$

A Korm. rendelet II. 2. \$ (1) bekezdése alapján a jótállási kötelezettség azt a vállalkozót terheli, aki a kivitelezési szerződés alapján az építési, szerelési munka elvégzésére kötelezettséget vállalt. A Korm. rendelet II. 2. \$ (2)-(3) bekezdései megteremtik a fogyasztó számára kedvezőbb jótállási feltételeket biztosításának lehetőségét, kimondva ugyanakkor, hogy semmis az a megállapodás, amely a rendeletben foglaltaktól a megrendelő hátrányára tér el. A jótállás időtartama, differenciáltan kerültmeghatározásraa szerződésközvetett tárgyátólfüggően, három (1. és 2. mellékletben meghatározottakra), öt (3. mellékletben meghatározottakra) vagy tíz éves időtartamban (4. mellékletben meghatározottakra), amely határidők jogvesztőek. A Korm. rendelet II. 3. \$(2) bekezdése alapján a jótállási jogokat a lakás (lakóépület) vagy építmény tulajdonosa, a lakás vagy építmény tulajdonba adásáig a megrendelő a vállalkozóval vagy az általa javításra kijelölt személlyel, illetve szervezettel szemben érvényesítheti, jótállási jeggyel, amelyet a vállalkozó lakásonként külön-külön köteles kiállítani. ${ }^{44}$

A Korm. rend. II. 4. \$ (3)-(4) bekezdéseiben foglalt szabályok meghatározzák a jótállási jegy kötelező tartalmi is. A Korm. rendelet II. 5. \$ (1)-(2) bekezdései pedig a jótállási igények intézésnek speciális szabályait rögzítik, így

- a vállalkozó a bejelentett jótállási igény alapján tizenöt napon belül köteles a hibát megvizsgálni és a jogosult igényéről nyilatkozni;

- a javítást, a cserét, a munka újbóli elvégzését úgy kell teljesíteni, hogy az lehetőség szerint a lakóépület, illetőleg a lakás használatát ne akadályozza.

43 Fővárosi Îtélőtábla 3.Pf.20.240/2014/3.

44 A kötelezettség egyébként megfelel az 1999/44/EK irányelv 6. cikk (3) bekezdésében foglaltaknak. 
Végezetül megemlítendő, hogy a Korm. rendelet III. mellékletében felsorolt, fogyasztó és vállalkozás közötti szerződés tárgyát képező, a fogyasztó által megrendelt, húsz ezer forintot meghaladó díjú javító-karbantartó szolgáltatás esetén a szolgáltatást nyújtó vállalkozást 6 hónap időtartamra jótállási kötelezettség terheli. A határidő jogvesztő jellegü, és a szolgáltatás elvégzése után a dolognak a fogyasztó vagy megbízottja részére való átadásával, vagy - ha az üzembe helyezést a vállalkozás végzi - az üzembe helyezés napjával kezdődik.

A Korm. rend. III. 3. $\$$ (1) és (3)-(4) bekezdései szerint a vállalkozó az átadásakor jótállási jegyet köteles a fogyasztó rendelkezésére bocsátani. A Korm. rendelet III. 3. $\$(5)-(6)$ bekezdései alapján a jótállásból eredő jogok a jótállási jeggyel érvényesíthetők, amelynek a kötelező tartalmi elemeit a Korm. rendelet III. meghatározza. A jótállási jegy kiállításának elmaradása és helytelen kitöltése nem érinti a fogyasztó jótállásból eredő jogait. A vállalkozás a fogyasztó jótállási igényéről egyébként - a Korm. rendelet III. 4. \$ (1) és (4) bekezdéseire figyelemmel - jegyzőkönyvet köteles felvenni, ${ }^{45}$ amelynek tartalmát a jogszabály szintén meghatározza.

\subsection{A kötelező jótállás 2021. január 1-től hatályos módosított szabályai}

A Kormány a Korm. rendelet I. és II. módosítását 2020. július 12-én hirdette ki, melyek 2021. január 1-től alkalmazandók. ${ }^{46} \mathrm{~A}$ módosított jogszabályalapot biztosít a javítószolgálatok és a kötelezett közötti tájékoztatásra. A módosítás értelmében a javítószolgálat jótállási igény érvényesítése esetében köteles igazolható módon a vállalkozást értesíteni a termék kijavítását követő öt munkanapon belül a javítás elvégzéséről, arról, ha az ingó dologról megállapítható az első javítás alkalmával, hogy nem javítható, továbbá a javítás várható idejéről, ha az ingó dolog javítása előreláthatóan tizenöt napnál hosszabb időt vesz igénybe, végezetül, ha az ingó dolog javítása nem lehetséges harminc nap alatt. A módosítás visszafogottan igyekszik a Ptk. által előírt szabad bizonyítás minimális formai kellékeit előírni, amely természetesen távol áll a szavatossági és jótállási ügyekben igénybe vehető szakértői vizsgálat és névjegyzék kötelezővé tételétől, azonban

45 Három évig meg is kell öriznie a Korm. rendelet III. 4. \$ (6) bekezdése szerint.

46 A Kormány 270/2020. (VI. 12.) Korm. rendelete az egyes tartós fogyasztási cikkekre vonatkozó kötelező jótállásról szóló 151/2003. (IX. 22.) Korm. rendelet, valamint az egyes javító-karbantartó szolgáltatásokra vonatkozó kötelező jótállásról szóló 249/2004. (VIII. 27.) Korm. rendelet módosításáról 
a fogyasztók védelme érdekében minimális formai szempontokat határoz meg a szakvélemények formáját és tartalmát illetően.

A módosítás értelmében a tartós fogyasztási cikkek kötelező jótállásának határideje értéktől függően sávosan fog változni. A jótállás időtartama a 10000 forintot elérő, de 100000 forintot meg nem haladó eladási ár esetén egy év, 100 000 forintot meghaladó, de 250000 forintot meg nem haladó eladási ár esetén két év, 250000 forint eladási ár felett három év lesz.

A legszembetűnőbb változás, hogy a tartós fogyasztási cikkekre vonatkozó jótállás e rendeletben szabályozottak szerinti kivételekkel lesz csak jogvesztő. A módosítás értelmében, hasonlóan a Ptk.-ban szabályozott szavatossági jogokhoz, a fogyasztási cikk kijavítása esetén (kizárólag ebben az esetben) a jótállás időtartama meghosszabbodik a javításra átadás napjától kezdve azzal az idővel, amely alatt a fogyasztó a fogyasztási cikket a hiba miatt rendeltetésszerüen nem használhatta. A szavatossági határidők szabályozásától eltérően, ebben az esetben a jótállás nyugvása kizárólag a javítás időtartamára vonatkozik, nem alkalmazandó ugyanakkor a fogyasztási cikk cseréje miatti használatból kiesés időtartamára, illetve a dolognak a kicseréléssel vagy a kijavítással érintett része esetében sem kezdődik újból a jótállási határidő. A módosítás számos korábbi szabályozást egészít ki a gyakorlati igényeknek megfelelően (beüzemelést igénylő termékek esete, csomagolás sértetlenségének kérdésköre), szem előtt tartva a fogyasztó tájékoztatásának követelményét. Nevesíti az elektronikus jótállási jegyet és meghatározza formai, tartalmi követelményeit, elérhetővé tételének kötelezettségét. A jótállási igények érvényesíthetőségének megkönnyítése érdekében bővíti azon helyek listáját, ahol a jótállási igényt be lehet jelenteni (a vállalkozás székhelyén, bármely telephelyén, fióktelepén, és a vállalkozás által a jótállási jegyen feltüntetett javítószolgálatnál).

A jótállási igények érvényesítése szempontjából számos újítást hoz a módosítás, bevezetve a „szankciós csere és vételárvisszatérítés” külön szabályait. Ha a fogyasztási cikk nem javítható (első javítás alkalmával megállapítható) vagy háromszori javítást követően újból meghibásodik (negyedik hibánál), akkor azt a fogyasztó eltérő rendelkezésének hiányában 8 napon belül ki kell cserélni. Ha ez nem lehetséges, akkor a vállalkozás köteles a fogyasztási cikk ellenértékét 8 napon belül visszatéríteni. Ha a fogyasztási cikk kijavítására jótállás keretében a kijavítási igény vállalkozás részére való közlésétől számított harmincadik napig nem kerül sor, - a fogyasztó eltérő rendelkezése hiányában - a vállalkozás köteles a fogyasztási cikket a harminc napos határidő eredménytelen elteltét 
követő nyolc napon belül kicserélni. Ha a fogyasztási cikk cseréjére nincs lehetőség, a vállalkozás köteles a vételárat a harminc napos kijavítási határidő eredménytelen elteltét követő nyolc napon belül a fogyasztó részére visszatéríteni. A jogalkotó, a fogyasztó visszaélésszerü jogalkalmazásának elkerülésére törekedve, különösen a nagyobb értékű fogyasztási cikkek esetében állapít meg kivételeket e rendelkezések alkalmazása alól (az elektromos kerékpár, elektromos roller, quad, motorkerékpár, segédmotoros kerékpárra, személygépkocsi, lakóautó, lakókocsira, utánfutós lakókocsi, utánfutó stb.).

\section{Termékszavatosság}

A termékszavatosság jogdogmatikai elhelyezését illetően elsődleges problémát jelent, hogy a jogintézménynek nincsenek valódi tradíciói, sem a hazai jogrendszerben, sem a külföldi szabályozásokban. A termékszavatosság jogintézmények bevezetése jelentős szemléletváltást igényel, a relatív szerkezetű kötelmi viszonyok zárt jellegének („privity of contract”) doktrínája ugyanis mélyen az uniós tagállamok jogi tradícióiban gyökerezik, míg a közvetlen gyártói felelősség ilyen kiterjesztése igazi jogtörténeti tradíciókkal nem bír.

A termékszavatosság esetén szerződéses viszony keretében a fogyasztó közvetlenül a gyártóval szemben érvényesítheti kijavítás vagy kicserélés iránti igényeit. ${ }^{47}$ Észszerű, hogy csere esetén a kicserélt termékre, kijavítás esetén a termék kijavítással érintett részére vonatkozó kellékszavatossági kötelezettség a gyártót terheli a továbbiakban. A Ptk. 6:168. \$ (2) bekezdése alapján gyártónak minősül a termék előállítója és forgalmazója.

A Ptk. 6:168. $\$(1)$ bekezdése alapján a termékszavatossági igény kizárólag vállalkozás által, fogyasztónak eladott ingó dolog hibája esetén érvényesíthető a gyártóval szemben. ${ }^{48} \mathrm{~A}$ termék akkor hibás, ha

- nem felel meg a terméknek a gyártó által történt forgalomba hozatalakor hatályos minőségi követelményeknek, vagy

- nem rendelkezik a gyártó által adott leírásban szereplő tulajdonságokkal.

47 A Ptk. 6:168. $\$(1)$ bekezdése alapján a csere igénye szubszidiárius, akkor érvényesíthető, ha a kijavítás megfelelő határidőn belül, a fogyasztó érdekeinek sérelme nélkül nem lehetséges.

48 A termékszavatossági szabályok alkalmazásában a Ptk. 6:168. \$(2) bekezdése alapján gyártónak minősül a termék eloállítója és forgalmazója. 
A Ptk. 6:169. $\$(1)$ bekezdése alapján a fogyasztó a hiba felfedezése után késedelem nélkül köteles a hibát gyártóval közölni. A hiba felfedezésétől számított két hónapon belül közölt hibát késedelem nélkül közöltnek kell tekinteni. A közlés késedelméből eredő kárért a fogyasztó felelős. Ez a szabályozás összhangban áll a Ptk. 6:162. §-ban a kellékszavatosság kapcsán a hiba közlésére meghatározott szabályokkal. Az igényérvényesítési határidő ugyanakkor - a kellékszavatossági határidőktől eltérően - jogvesztő, a Ptk. 6:169. \$ (2) bekezdése alapján a gyártót a termékszavatosság az adott termék általa történő forgalomba hozatalától (tehát nem a fogyasztó által kötött szerződés teljesítésének időpontjától) számított két évig terheli.

A gyártó felelősség alóli mentesülésének eseteit tekintve hasonlóság fedezhető fel a termékfelelősség szabályai kapcsán korábban a hazai jogban már megismert egyes mentesülési esetekhez; ${ }^{49}$ így a Ptk. 6:168. \$ (3) bekezdése alapján a gyártó mentesül a termékszavatossági kötelezettség alól, ha bizonyítja, hogy

- a terméket nem üzleti tevékenysége, vagy önálló foglalkozása körében gyártotta, vagy forgalmazta;

- a termék forgalomba hozatalának időpontjában a hiba a tudomány és a technika állása szerint nem volt felismerhető; vagy

- a termék hibáját jogszabály, vagy kötelező hatósági előírás alkalmazása okozta.

Végül megemlítendő, hogy a Ptk. 6:170. \$ rendezi a tulajdonosváltozás esetét is; a termékszavatossági jogokat a termék tulajdonjogának átruházása esetén az új tulajdonos érvényesítheti a gyártóval szemben. Ez egyébként logikus megoldás, hiszen a gyártó közvetlen felelősségének biztosítására hivatottak a termékszavatosság szabályai.

49 Jelenleg a Ptk. 6:555. \$ (1) bekezdése 


\section{Szavatossági és jótállási igények érvényesítése fogyasztói szerződés esetén}

\subsection{A szavatossági és jótállási igények intézésének hatályos szabályai}

A fogyasztó és vállalkozás közötti szerződés keretében eladott dolgokra vonatkozó szavatossági és jótállási igények intézésének hatályos szabályait a 19/2014. (IV. 29.) NGM rendelet (a továbbiakban: NGM rendelet) határozza meg. Fontos hangsúlyozni, hogy e rendelet szabályai kizárólag akkor alkalmazhatók, ha az eladott ingó dolog hibája miatt a fogyasztó a Ptk. szerinti kellékszavatossági vagy termékszavatossági igényt vagy jogszabály alapján őt megillető jótállási igényt érvényesít.

Az NGM rendelet 3. \$(1) bekezdése alapján a szavatossági igénye érvényesítésekor magát a szerződés megkötését a fogyasztónak kell bizonyítania. Garanciális jelentőségű szabály ugyanakkor, hogy

- ha a vállalkozás a szerződés megkötését vitatja, köteles felhívni a fogyasztó figyelmét a panasztétel lehetőségére és a panasz intézésének - a fogyasztóvédelemről szóló törvényben foglaltakkal összhangban álló - módjára,

- a szerződés megkötését bizonyítottnak kell tekinteni, ha az ellenérték megfizetését igazoló bizonylatot - az általános forgalmi adóról szóló törvény alapján kibocsátott számlát vagy nyugtát - a fogyasztó bemutatja. ${ }^{50}$

Az NGM rendelet 4. $\$(1)-(6)$ bekezdései rögzítik, hogy a vállalkozás a fogyasztó nála bejelentett szavatossági vagy jótállási igényéről jegyzőkönyvet köteles felvenni és azt három évig megőrizni, amelyben rögzíti a kifogás legfontosabb adatait, a felek és a termék megnevezését, a hiba leírását, a fogyasztó igényét, kitanítást a fogyasztói jogérvényesítés lehetőségeiről.

A jegyzőkönyv felvételének kötelezettsége nem a meghibásodás okától, és nem a forgalmazó szubjektív szakmai megítélésétől vagy válaszától függ, hanem az a jogalkotó objektív elvárása a fogyasztói igény érvényesítése, tehát a bejelentés esetén; így ezen jogszabályi kötelezettség teljesítése különböző indokokkal nem kerülhető meg. ${ }^{51}$

50 NGM rendelet 3. $\$(1)-(2)$ bekezdései

51 Legfelsőbb Bíróság Kfv.IV.37.022/2007/6. 
Az igények intézésének fogyasztó szempontjából garanciális jelentőségű szabályait is megfogalmazza az NGM rendelet 5 . \$-a és 7 . \$-a, meghatározza a vállalkozás kötelezettségét, hogy törekedjen a kijavítás vagy kicserélés legfeljebb tizenöt napon belüli elvégzésére, valamint azt, hogy a fogyasztó kijavítás iránti igényét közvetlenül a jótállási jegyen feltüntetett javítószolgálatnál is érvényesítheti. A márkaszerviz, ha javításokat végez, e körben ugyanis a forgalmazó teljesítési segédje. Ekként pedig tehet jognyilatkozatot a saját nevében a jótállási igények érvényesítésével összefüggésben. ${ }^{52}$

\subsection{A fogyasztó szavatossági és jótállási igényeinek 2021. január 1-tôl hatályos szabályai ${ }^{53}$}

A módosított NGM rendelet különbséget tesz szavatossági igények vagy áruk jogszabályon alapuló jótállásának érvényesítése között. A vállalkozásnak változatlanul törekednie kell arra, hogy szavatossági jogkörben a kijavítást vagy kicserélést legfeljebb tizenöt napon belül elvégezze, ugyanakkor, ha a kijavítás vagy a kicserélés időtartama a tizenöt napot meghaladja, akkor a vállalkozás a fogyasztót tájékoztatni köteles a kijavítás vagy a csere várható időtartamáról.

A módosított NGM rendelet alapot biztosít a javítószolgálatok és a kötelezett vállalkozás közötti tájékoztatásra, amely eddig nem állt fent, tekintettel arra, hogy a javítószolgálat rendszerint a gyártó (importőr) megbízottjaként járt el. A módosítás értelmében a javítószolgálat jótállási igény érvényesítése eseténköteles igazolható módon a vállalkozást értesíteni a termék kijavítását követő öt munkanapon belül a javítás elvégzéséről, arról, ha az ingó dologról megállapítható az első javítás alkalmával, hogy nem javítható, továbbá a javítás várható idejéről, ha az ingó dolog javítása előreláthatóan tizenöt napnál hosszabb időt vesz igénybe, végezetül, ha az ingó dolog javítása nem lehetséges harminc nap alatt. A módosítás visszafogottan igyekszik a Ptk. által elöírt szabad bizonyítás minimális formai kellékeit előírni, amely természetesen távol áll a szavatossági és jótállási ügyekben igénybe vehető szakértői vizsgálat és névjegyzék kötelezővé tételétől, azonban a fogyasztók védelme érdekében minimális formai szempontokat határoz meg a szakvélemények formáját és tartalmát illetően.

52 Fővárosi Ítélőtábla 3.Pf.21.222/2011/3.

53 Az innovációért és technológiáért felelös miniszter 18/2020. (VI. 12.) ITM rendelete a fogyasztó és vállalkozás közötti szerződés keretében eladott dolgokra vonatkozó szavatossági és jótállási igények intézésének eljárási szabályairól szóló 19/2014. (IV. 29.) NGM rendelet módosításáról 


\section{Kártérítési felelősség}

A szerződésszegéssel okozott károkért való felelősség körében a Ptk. 6:142. $\$$ rögzíti, hogy aki a szerződés megszegésével a másik félnek kárt okoz, köteles azt megtéríteni. Mentesül ugyanakkor a felelősség alól, ha bizonyítja, hogy

- a szerződésszegést ellenőrzési körén kívül eső,

- a szerződéskötés időpontjában előre nem látható körülmény okozta, és

- nem volt elvárható, hogy a körülményt elkerülje vagy a kárt elhárítsa.

A kártérítés mértéke tekintetében a Ptk. 6:143. \$(1)-(2) bekezdésében meghatározottak szerint irányadó, hogy szolgáltatás tárgyában keletkezett károk (ún. tapadó károk) esetében továbbra is a teljes kártérítés elve érvényesül, míg az elöreláthatósági kritérium csak az egyéb károk és az elmaradt vagyoni előny esetében releváns. $^{54}$

Újdonság, hogy a Ptk. 6:145. \és 6:146. \$ direkt módon kizárja a párhuzamos kártérítési igények érvényesítését (non-cumul szabály). Egyrészt a jogosult kártérítési igényét a kötelezettel szemben akkor is a szerződésszegéssel okozott károkért való felelősség szabályai szerint érvényesítheti, ha a kár a kötelezett szerződésen kívül okozott károkért való felelősségét is megalapozza. Emellett pedig a jogosult vagyonában a teljesítés során a kötelezett által okozott kár megtérítése vonatkozásában is a kontraktuális felelősség szabályai alkalmazandók.

Hibás teljesítésről eleve csak akkor lehet szó, ha a hiba oka már a teljesítéskor megvolt a szerződéses szolgáltatásban, vagyis a kötelezett hibás szolgáltatást nyújtott a jogosult részére. Ha a szolgáltatás a teljesítést követően felmerült okból hibásodik meg, a hibás teljesítés mint szerződésszegés nem következik be. ${ }^{55}$ A Ptk. 6:174. \$ (1) bekezdése ekként logikus distinkciót téve a szerződésszegéssel okozott károkra vonatkozó általános szabályokhoz képest a kötelezett kártérítési felelőssége alóli kimentési lehetőségeit bővíti a hibás teljesítés kimentésének lehetőségével.

54 Ezeket olyan mértékben kell megtéríteni, amilyen mértékben a jogosult bizonyítja, hogy a kár mint a szerződésszegés lehetséges következménye a szerződés megkötésének időpontjában előre látható volt. Megjegyzendő azonban, hogy szándékos szerződésszegés esetén a jogosult teljes kárát meg kell téríteni.

55 Kúria Pfv.V.20.158/2014/4. 
A jogosultnak a hibás teljesítés folytán többféle vagyoni érdeksérelme, kára keletkezhet, így

- vagyoni hátrány egyrészt abban jelentkezhet, hogy maga a szerződéses szolgáltatás hibás; ez az ún. tapadókár,

- a hibás teljesítés elindíthat egy olyan oksági folyamatot, amelynek következtében a jogosult egyéb vagyontárgyai károsodhatnak, illetve a vagyoni hátrány elhárítása érdekében a jogosultnak kiadásai keletkezhetnek, vagy jövedelemtől, haszontól eshet el; ezek az ún. következménykárok. ${ }^{56}$

A tapadó károk vonatkozásában a Ptk. 6:174. \$ (2) bekezdése rögzíti, hogy megtérítését a jogosult akkor követelheti, ha

- kijavításnak vagy kicserélésnek nincs helye, vagy

- ha a kötelezett a kijavítást vagy a kicserélést nem vállalta, e kötelezettségének nem tud eleget tenni, vagy

- ha a jogosultnak a kijavításhoz vagy kicseréléshez füződő érdeke megszűnt.

Fontos megszorítás továbbáa Ptk. 6:174. \$(2) bekezdésében, hogy a kártérítési igény a kellékszavatossági jogok érvényesítésére meghatározott határidőn belül évül el. Ez azért fontos, mert e rendelkezés biztosítja a jogok rendeltetésszerü gyakorlását is, hiszen a jogosultat elzárja a kárigények érvényesítésétől is a szavatossági jogok megfelelő határidőn belül történő érvényesítésének elmulasztása esetén. ${ }^{57}$ Egyébként a jogosult kártérítési igényét az ugyanabból a szerződésből eredő követeléssel szemben kifogásként akkor is érvényesítheti, ha a kártérítési igény elévült.

Jelenleg tehát a Ptk. 6:174. $\$(2)$ bekezdése a tapadó károkhoz kapcsolódó szabályokat határozza meg, ugyanakkor nem kizárt a következménykárok megtérítésére irányuló igény érvényesítése sem, amelyre azonban - eltérő szabályok hiányában - a Ptk. 6:142. \$-6:144. \$-ok rendelkezései megfelelően irányadóak. ${ }^{58}$

56 Kúria Pfv.V.22.165/2012/6.

57 Czirfusz Gy.: Szavatosság és/vagy kártérítés a hibás teljesítés miatt. Polgári Jogi Kodifikáció, 2007/4. 31-35., http://ptk2012.hu/wp-content/uploads/2012/10/2007-04kodi.pdf (letöltés dátuma: 2020.03.06.)

58 Figula I., Rosnerné Romenda Zs., Gyarmathy J., Szabó P.: PTK Hatodik könyv: Kötelmi jog - A kötelmek közös szabályai. (PTK e-learning), Magyar Igazságügyi Akadémia, 2014., http://projektjeink.birosag.bule-learning/ptk (letöltés dátuma: 2015.03.06.) 


\section{Forrásjegyzék}

I. Czirfusz Gy.: Szavatosság és/vagy kártérítés a hibás teljesítés miatt. Polgári Jogi Kodifikáció, 2007/4. 31-35., http://ptk2012.hu/wp-content/ uploads/2012/10/2007-04kodi.pdf (letöltés dátuma: 2020. 03. 06.)

2. Figula I., Rosnerné Romenda Zs., Gyarmathy J., Szabó P.: PTK Hatodik könyv: Kötelmi jog - A kötelmek közös szabályai. (PTK e-learning), Magyar Igazságügyi Akadémia, 2014., http://projektjeink.birosag.hulelearning/ptk (letöltés dátuma: 2015. 03. 06.)

3. Fuglinszky Á.: Fogyasztói adásvétel, kellék-és termékszavatosság. Wolters Kluwer, Budapest, 2016.

4. Hámori A.: A fogyasztóvédelem közigazgatási „útvesztői”: (a „fogyasztó” fogalom „dilemmái”). In: Majoros P. (szerk.): BGF Tudományos Évkönyv 2008: Kultúraközi párbeszéd az üzleti világban. Budapesti Gazdasági Főiskola, Budapest, 2009. 150-166.

5. G. Howells, R. Schulze (eds): Modernising and Harmonising Consumer Contract Law: With Reference to the Planned Horizontal Consumer Contract Directive. Sellier, Munich, 2009.

6. Joó I.: A közvetlen gyártói felelősség kiterjesztése a „privity of contract” elvének terhére. Glossa Iuridica, Vol. 2, 2011/1. 94-97.

7. Papp T.: Mit takar a fogyasztó kategóriája? Céghirnök, 2013/2. 4-6.

8. B. Pasa, G. A. Benacchio: The harmonization of civil and commercial law in Europe. Central European University Press, Budapest, 2005.

9. Szikora V.: A fogyasztóvédelmi jog történeti kialakulása Európában, különös tekintettel a magánjog-egységesítési folyamatokra. In: Szikora V. (szerk.): Magyar fogyasztóvédelmi magánjog - európai kitekintéssel. Center Print Nyomda, Debrecen, 2010. 19-30.

IO. VArGa N.: Gondolatok a fogyasztói szerződési jog kialakulásáról és fejlődéséről. Debreceni Jogi Mühely, Vol. 10, 2013/3, 138-157. https:// mad-hatter.it.unideb.hu/portal/displayDocument/id/2482204ol. (letöltés dátuma: 2020.02.10.)

II. VÉKÁs L.: Az európai közösségi magánjog sajátos alanyáról: a „fogyasztó” fogalmáról. Európai Jog, 2002/5. 3-13. 
12. 1959. évi IV. törvény a Polgári Törvénykönyvről

13. 2002. évi XXXVI. törvény a Magyar Köztársaság Polgári Törvénykönyvéről szóló 1959. évi IV. törvény, valamint egyes törvények fogyasztóvédelemmel összefüggő jogharmonizációs célú módosításáról

14. 2008. évi XLVII. törvény a fogyasztókkal szembeni tisztességtelen kereskedelmi gyakorlat tilalmáról

15. 2013. évi V. törvény a Polgári Törvénykönyvről

16. 151/2003. (IX. 22.) Korm. rendelet az egyes tartós fogyasztási cikkekre vonatkozó kötelező jótállásról

17. 181/2003. (XI. 5.) Korm. rendelet a lakásépítéssel kapcsolatos kötelező jótállásról

18. 249/2004. (VIII. 27.) Korm. rendelet az egyes javítókarbantartószolgáltatásokra vonatkozó kötelező jótállásról

19. 270/2020. (VI. 12.) Korm. rendelet az egyes tartós fogyasztási cikkekre vonatkozó kötelező jótállásról szóló 151/2003. (IX. 22.) Korm. rendelet, valamint az egyes javító-karbantartó szolgáltatásokra vonatkozó kötelező jótállásról szóló 249/2004. (VIII. 27.) Korm. rendelet módosításáról

20. 19/2014. (IV. 29.) NGM rendelet a fogyasztó és vállalkozás közötti szerződés keretében eladott dolgokra vonatkozó szavatossági és jótállási igények intézésének eljárási szabályairól

21. 18/2020. (VI. 12.) ITM rendelete a fogyasztó és vállalkozás közötti szerződés keretében eladott dolgokra vonatkozó szavatossági és jótállási igények intézésének eljárási szabályairól szóló 19/2014. (IV. 29.) NGM rendelet módosításáról

22. 1/2012. (VI. 21.) PK vélemény a hibás teljesítéssel kapcsolatos egyes jogalkalmazási kérdésekről

23. Európai Unió Bíróságának C-110/14. sz. Horațiu Ovidiu Costea v. SC Volksbank România SA ügyben 2015. szeptember 3-án hozott ítélete (ECLI:EU:C:2015:538)

24. Legfelsőbb Bíróság Kfv. III. 37.675/2003. sz. ügyben hozott ítélete

25. Legfelsőbb Bíróság Kfv. III. 37.091/2004. sz. ügyben hozott ítélete

26. Legfelsőbb Bíróság Kfv.IV.37.022/2007/6. sz. ítélete

27. Legfelsőbb Bíróság Kfv.III.37.027/2007/4. sz. ítélete

28. Kúria Pfv.V.21.203/2012/6. sz. ítélete

29. Kúria Pfv.V.21.825/2012/9. sz. ítélete 
30. Kúria Kfv.III.37.038/2013/4. sz. ítélete

31. Kúria Pfv.V.20.158/2014/4. sz. ítélete

32. Kúria Pfv.IV.20.366/2014/5. sz. ítélete

33. Kúria Pfv.V.20.369/2014/4. sz. ítélete

34. Győri Ítélőtábla Gf.II.20.099/2009/13. sz. ítélete

35. Győri Ítélőtábla Pf.II.20.271/2013/8. sz. ítélete

36. Szegedi Ítélőtábla Pf.I.20.564/2011/10. sz. ítélete

37. Szegedi Ítélőtábla Gf.I.30.039/2011/3. sz. ítélete

38. Szegedi Ítélőtábla Gf.I.30.253/2013/2. sz. ítélete

39. Szegedi Ítélőtábla Pf.II.20.049/2013/3. sz. ítélete

40. Szegedi Ítélőtábla Pf.II.20.445/2014/3. sz. ítélete

41. Fővárosi Ítélőtábla 3.Pf.21.222/2011/3. sz. ítélete

42. Fővárosi Ítélőtábla 3.Pf.20.24/2014/3. sz. ítélete

43. Fővárosi Törvényszék 3.Pf.21.536/2009/5. sz. ítélete 
Dr. Fézer Tamás habil, PhD., a Debreceni Egyetem Állam- és Jogtudományi Karának egyetemi tanára, valamint a kar fejlesztési és külkapcsolati dékánhelyettese. A kar angol nyelvü European and International Business Law LL.M mesterképzésének szakfelelőse. PhD fokozatát felelősségi jogból szerezte 2009-ben. Kutatási területet a kötelmi jog, a nemzetközi üzleti jog és a polgári jogi felelősség témaköreit érinti. 2008-ban Fulbright ösztöndíjasként folytatott kutatásokat és európai magánjogot oktatott az amerikai Indiana University jogi karán. 2010-ben az Állami Eötvös Ösztöndíj támogatásával tért vissza az Egyesült Államokba, ahol a termékfelelősség körében végzett összehasonlító jogi kutatásokat. Számos alkalommal volt vendégoktató Ausztriában, Spanyolországban, Szlovákiában, Romániában, Kínában, Oroszországban, Indonéziában és az Egyesült Államokban. Tagja a Kúria elnöke által alapított új Ptk. jogértelmezési kérdéseivel foglalkozó Tanácsadó Testületnek. 2015ben a Nemzeti Kiválóság Program Magyary Zoltán Posztdoktori Ösztöndíját, 2016-2019 között pedig a Magyar Tudományos Akadémia Bolyai János Kutatási Ösztöndíját nyerte el. Külső jogi szakértője a brüsszeli székhelyű Milieu Consulting Sprl-nek, melynek égisze alatt az Európai Bizottság és az Európai Parlament részére végez üzleti jogot, magánjogot és alapjogokat érintő kutatásokat.

Dr. Hajnal Zsolt PhD., 2003-ban szerzett jogász diplomát a Debreceni Egyetem Állam- és Jogtudományi Karán. 2002-től a Fogyasztóvédők Magyarországi Egyesületének elnöke, 2007-től a Hajdú-Bihar megyei Békéltető Testület elnöke. Disszertációját 2013-ban védte meg. A Debreceni Egyetem Állam és Jogtudományi Kar egyetemi adjunktusaként fogyasztóvédelmi jogot, európai jogot, nemzetközi magánjogot tanít. 2017-ben a Tudományos Diákkörben végzett eredményes munkájáért mestertanári aranyérem kitüntetést kapott. 2020-ban szakmai tevékenységének köszönhetően a Fogyasztóvédelemért miniszteri kitüntetésben részesült. 